\title{
Structural Analysis and Redesign of a Cable-Stayed Suspension Bridge across Achankovil River in Kerala
}

\author{
Thasnem Fathima ${ }^{1}$, Jincy K Jose ${ }^{2}$, Aparna E N ${ }^{3}$, Renjana R S ${ }^{4}$, Rajeev Kumar $\mathrm{P}^{5 *}$ \\ $1,2,3,4$ IV yr B. Tech students; ${ }^{5}$ Professor \\ Department of Civil Engineering \\ Musaliar College of Engineering \& Technology, Pathanamthitta, Kerala
}

\begin{abstract}
This technical paper highlights the project work pertaining to the structural analysis and redesign of a suspension cabled-bridge using a computer software, STAAD.Pro ${ }^{\circledR}$. Various load-combinations were included in the frame analysis and worked on every aspect of the redesign. This included the design of the actual replacement of bridge deck, the effect this bridge would have on the surrounding area through an environmental impact, and the logistics associated with the construction phase. Design was done manually using relevant codes also. Drawings were done in $A u t o C A D^{\circledR}$. Such a work would enable the economic redesign of the existing suspension bridge.
\end{abstract}

Keywords- Structural analysis; design, STAAD.Pro ${ }^{\circledR}$, AutoCAD ${ }^{\circledR}$, cable-stayed suspension bridge

\section{INTRODUCTION}

Suspension bridges are longest span structures, however, the major problem of those structures are its low lateral stiffness. The suspension cable is the major element of such bridges; moreover, it is the key of the analysis. The challenge in suspension cable analysis is the material and geometrical nonlinearities; the acting forces change cable cross section and extend the cable; as a result to that deformation the young's modulus changes. For simplifying the analysis, the cable was analyzed as a catenary and it is a reasonable hypothesis to some extent; In contrast, more realistic and sophisticated analysis methods were proposed using Finite Element method considering nonlinearities issues.

Many researchers have conducted works in this area [1][4]. Objective of this paper is to perform the structural analysis and redesign of the existing cable-stayed suspension bridge across Achankovil river in Konni Panchayath, Pathanamthitta district, Kerala state, as shown in Figures 1 and 2. It is thought that such a study would help to perform an economical and environment friendly redesign of the existing bridge at this location.

\section{LOCATION DETAILS OF THE SITE}

It was found that hundreds of children who depend on ferry boats, operated between the Iyravon temple ghats and the Cheeckanattu Kadavu , to reach schools in Konni. The decision to construct 52 steel, hanging foot bridges at various places in the state was taken on in the backdrop of the ferry accident in Kozhikode one year ago. The services of a 14 member team from Kozhikode was enlisted to complete the work in a time bound manner. The bridge was 65 meter long,1.5 meter wide bridge would cost Rs 47.22 lakh on the completion.

The bridge was constructed across Achankovil river, connecting the panchayaths viz-a-viz Konni and Aruvappulam. The direction of flow is from the East to the West direction. There are a few houses located near the bridge. The current bridge is not useful for pedestrian crossing, so there is a necessity of new bridge. This bridge saves travel time by $1 \mathrm{hr}$. During the flood situation in 2018, it was difficult use the ferry and this bridge was the life-line for the local community. It is a simple and accessible way of people for local transportation. There is a temple named Puthiyakavu Bhagavathy Temple in the banks of the river. Without this bridge, travel distance is longer. STAAD.Pro ${ }^{\circledR}$ (2018) and AutoCAD ${ }^{\circledR}$ (2018) are used in the analysis and design methodology. Following is the details of analysis and design of the new cable-stayed suspension bridge for the objective mentioned above.

\section{ANALYSIS AND DESIGN OF SUSPENSION BRIDGE}

The cable-stayed suspension bridge connects the two panchayaths as mentioned above. The flow of Achankovil river is shown in the Figures 3 and 4. The main anchor blocks are anchored at the end of the roads. A-shaped towers are placed at each end and are supported by pier foundation. The total span of the bridge is $60 \mathrm{~m}$ and the width of deck is $1.5 \mathrm{~m}$. The deck thickness is $0.1 \mathrm{~m}$. The hangers are provided with steel pipes which are more suitable than steel ropes. A handrail is provided at a height of $1.5 \mathrm{~m}$ from the base plates. A number of steel base plates are used for the steel deck. A steel wire mesh is also provided for protection. Details of the existing bridge are given in Table 1 .

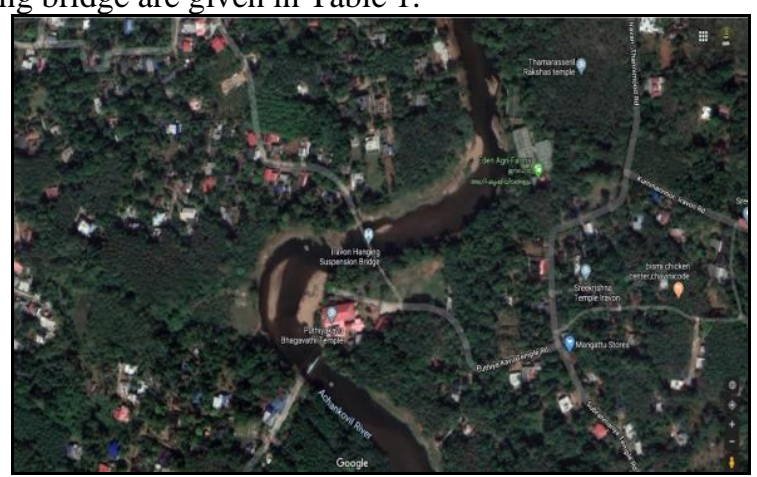

Fig. 1. Location map of the site 
TABLE I. DETAILS OF EXISTING SUSPENSION BRIDGE

\begin{tabular}{|c|c|}
\hline District/State & Pathanamthitta/Kerala \\
\hline Municipality/Taluk & Ayravon \\
\hline Name of river & Achankovil river \\
\hline Type of Bridge & Suspension bridge \\
\hline Span / Total span & $60 \mathrm{~m}$ \\
\hline Breadth & $1.5 \mathrm{~m}$ \\
\hline Thickness of deck & $0.1 \mathrm{~m}$ \\
\hline
\end{tabular}

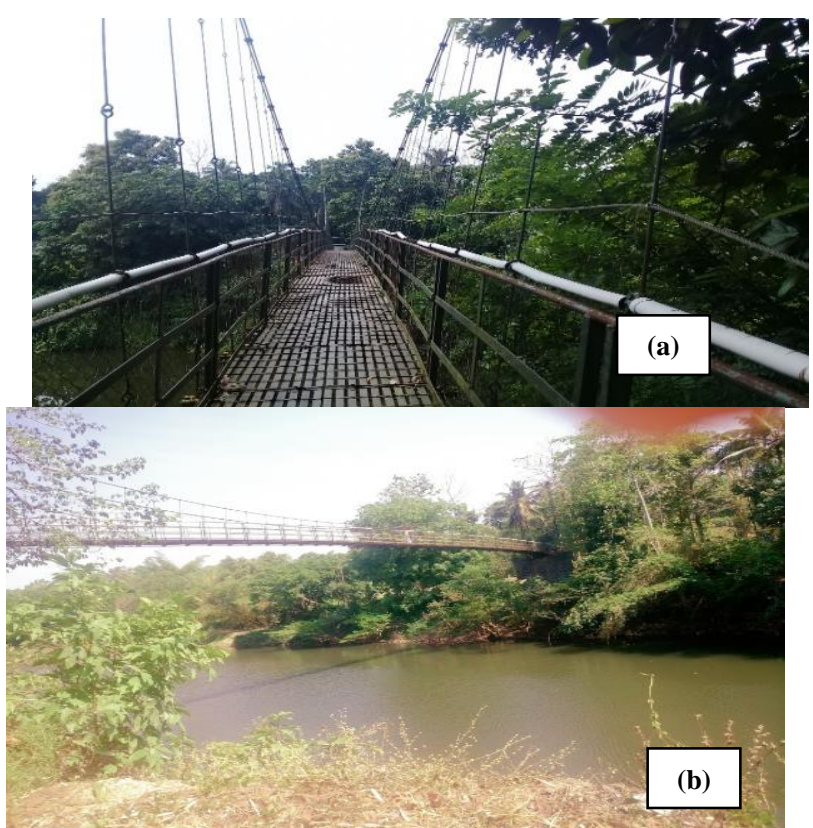

Fig. 2. Details of existing bridge: (a) bridge deck, (b) view from the south

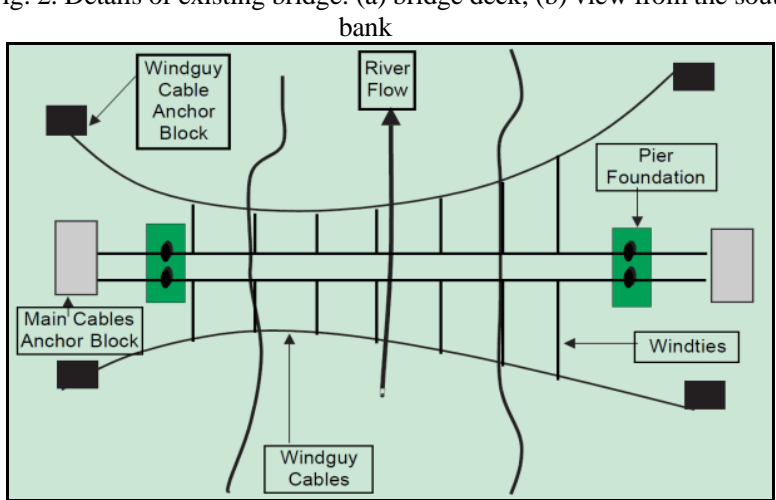

Fig 3. Plan view of suspension bridge

\section{A. Design Procedure}

For the design of the cable stayed suspension bridge, the details of the existing bridge were collected from the respective Panchayath office. Detailed study was conducted to identify the reason for failure of the existing bridge. For the analysis and redesign STAAD.Pro ${ }^{\circledR}$ (2018) software was used. STAAD.Pro ${ }^{\circledR}$ (2018) is customized for modelling, analysis and design of suspension bridge and cannot be used to design a flyover because it lacks the user interface to model such a structure. Suspension bridges tend to be the most expensive to build. A suspension bridge suspends the roadway from huge main cables, which extend from one end of the bridge to the other. These cables rest on top of high towers and have to be securely anchored into the bank at either end of the bridge. The towers enable the main cables to be draped over long distances.

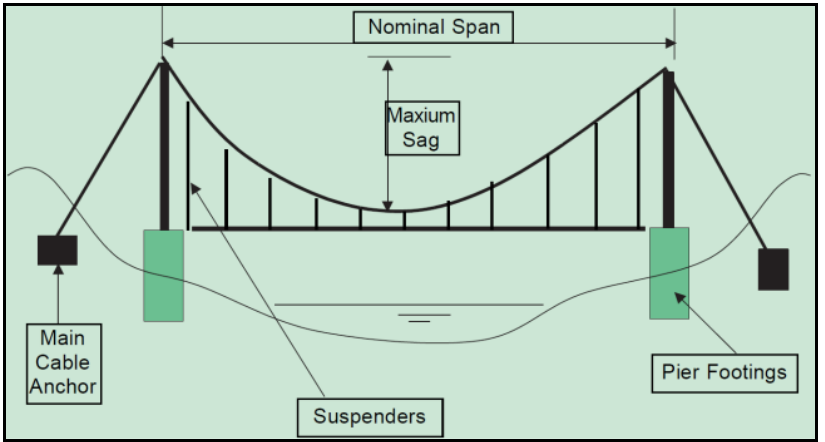

Fig 4.Side view of suspension bridge

Most of the weight or load of the bridge is transferred by the cables to the anchorage systems. These are imbedded in either solid rock or huge concrete blocks. Inside the anchorages, the cables are spread over a large area to evenly distribute the load and to prevent the cables from breaking free.

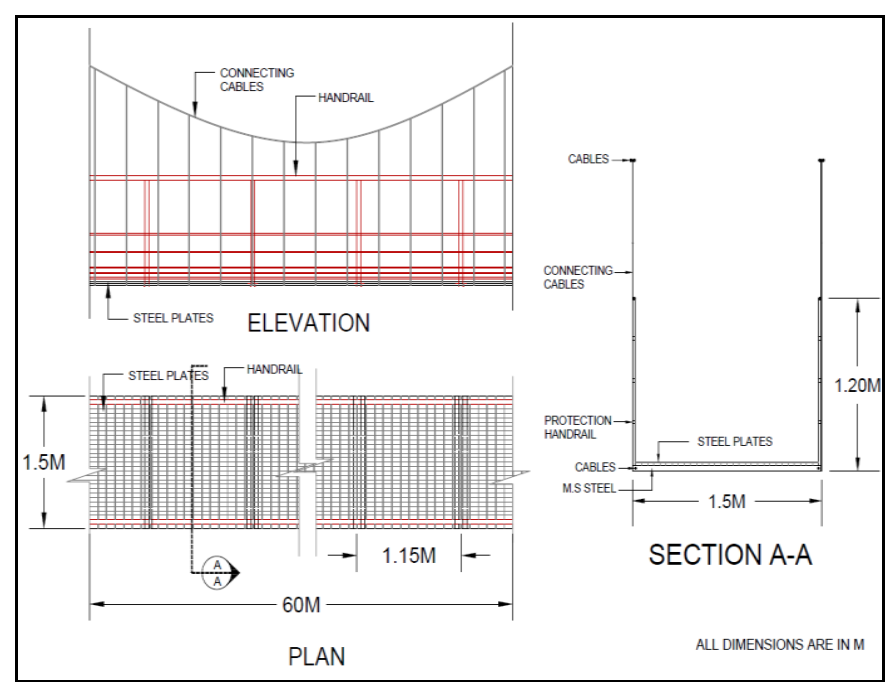

Fig 5.AutoCAD ${ }^{\circledR}$ drawing of the new suspension bridge

The planned suspension cable bridge is modeled in STAAD.Pro ${ }^{\circledR}$. Various loads and combinations are included in the frame analysis also included lateral loads. Structural design is to be done using Limit state method.

\section{MATERIAL:}

- Grade of reinforcement : Fe 415

- Grade of concrete: M25

- Density of concrete $: 2500 \mathrm{~kg} / \mathrm{m}$

\section{B. Design Specifications}

The preliminary design was based on the Indian Standards and Design Manual for Bridges and Structures. The terrain profile at the proposed site is flat with minimal variations in the ground levels. The longitudinal gradient of the structure was restricted to $5 \%$. Cables are the fundamental elements in cable-supported structures. For that reason, choosing among the different existing types requires special consideration.

The general characteristics of the steel used :

- Yield strength: 1180 MPA

- Tensile strength: 1570 MPA

- Modulus of elasticity: 205GPA 
- Chemical composition: $0.8 \% \mathrm{C}, 0.2 \% \mathrm{Si}, 0.6 \% \mathrm{Mn}$, $0.05 \% \mathrm{Cu}, 0.05 \% \mathrm{Ni}, 0.05 \% \mathrm{Cr}, 0.03 \% \mathrm{P}, 0.02 \% \mathrm{~S}$.

The cables commonly used for footbridge construction are the nominal sizes $13 \mathrm{~mm}, 19 \mathrm{~mm}$ and $26 \mathrm{~mm}$. Cable and member connections are chosen to meet safe limits.

\section{C: Load Calculations:}

The dead load is the total weight of all the permanent components of the footbridge structure. These include: selfweight of the main cables deck (steel or timber),cross bracings, side wire mesh, suspenders, hand rails, wind-guy cables, diagonal stabiliser, connections etc. The load of a passenger was considered as $50 \mathrm{~kg}$. An average of 10 people was considered at a time over the bridge.

Live load is calculated from the formula, $\mathrm{p}=(3+50 / \mathrm{L})$, where $\mathrm{p}\left(\mathrm{kN} / \mathrm{m}^{2}\right)$ is the live load uniformly distributed along the span. The wind velocity and wind loads can be calculated using IS 875 Part 3-1987. The wind load can be calculated using the Indian standards IS: 875(Part 3)-1987. The basic wind speed corresponding to Konni region is taken from the code IS:875 (Part 3)-1987.

The wind load is calculated from the assumed wind velocity and is taken as a uniformly distributed load with a predominately horizontal component.

- For effective spans over $30 \mathrm{~m}$, the UDL may be calculated as given below:

$$
\mathrm{P}=\frac{1}{100}\left(13.3+\frac{400}{L}\right)\left(\frac{17-W}{1.4}\right) \mathrm{kN} / \mathrm{m}^{2}
$$

where,

$\mathrm{P}=$ Live load in $\mathrm{kN} / \mathrm{m}^{2}$

$\mathrm{L}=$ Effective span of the bridge in $\mathrm{m}$.

$\mathrm{W}=$ Width of the foot path in $\mathrm{m}$

Seismic loads are calculated in accordance with is IS1893: 1984. Earthquakes cause vertical and horizontal forces in the structure that will be proportional to the weight of the structure.

D: Analysis of Suspension Bridge using STAAD.Pro

The primary objectives were:

1. Creation of structural plan

2. Creation of STAAD model

3. Application of loads on the member

4. To analyze the bridge using STAAD Pro.V8i (2018)

5. To design the superstructure of the bridge.

The whole structure was created by giving steel plates of grade ISMB300, Pipes of grade PIP761L, T section of grade ISNT150. The dead loads, live loads, wind loads and dynamic loads were applied and the whole structure was created. Shear force diagram, bending moment diagram, wind load diagram, deflection diagram, and 3D structure diagram are shown in Figures 6 to 11.

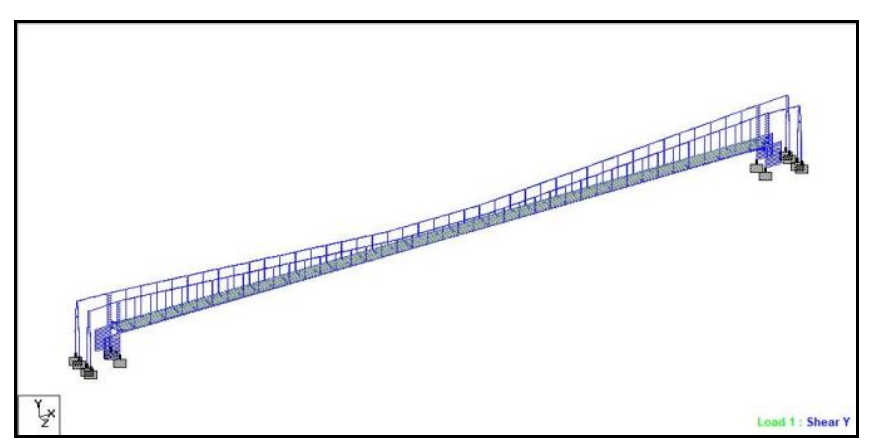

Fig. 6 Shear force diagram

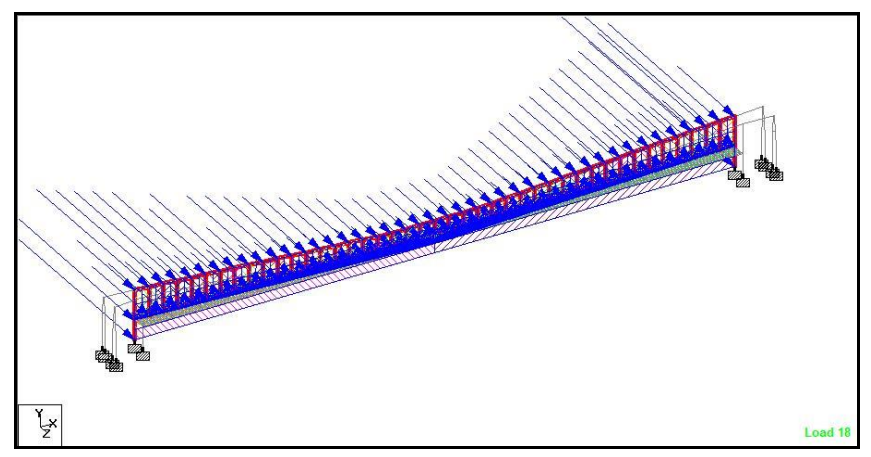

Fig. 7 Wind load diagram 1



Fig. 8 Wind load diagram 2



Fig. 9 Deflection diagram 


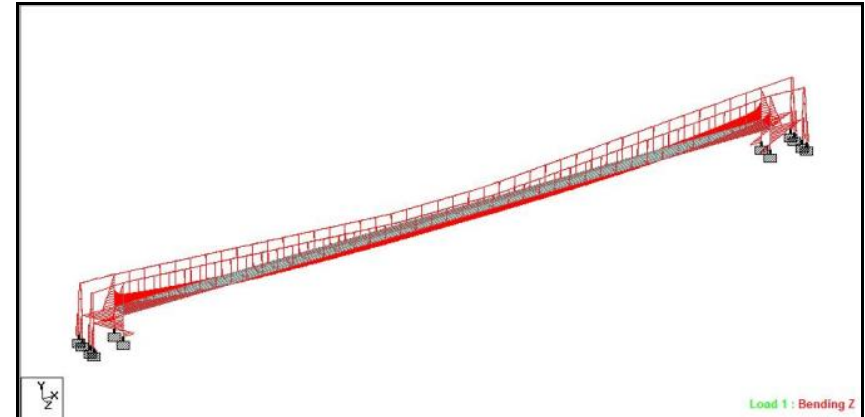

Fig.10 Bending moment diagram

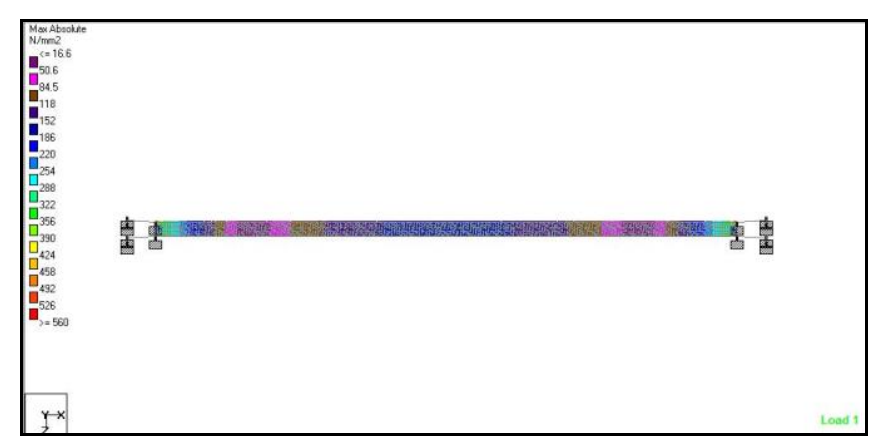

Fig. 11 Maximum absolute stress

\section{E: $3 D$ Structure}

A three-dimensional (3D) model of the structural system was required to capture the response of the entire bridge system and individual components under specific characteristics. The interaction between the response in the orthogonal bridge directions and the variation of axial loads throughout the analysis are captured more accurately in a 3D model (Fig. 12). This enables correct evaluation of the capacity and ductility of the system under displacements applied along any given direction, not necessary aligned with the principal axis of the bridge. (STAAD.Pro, 2018).

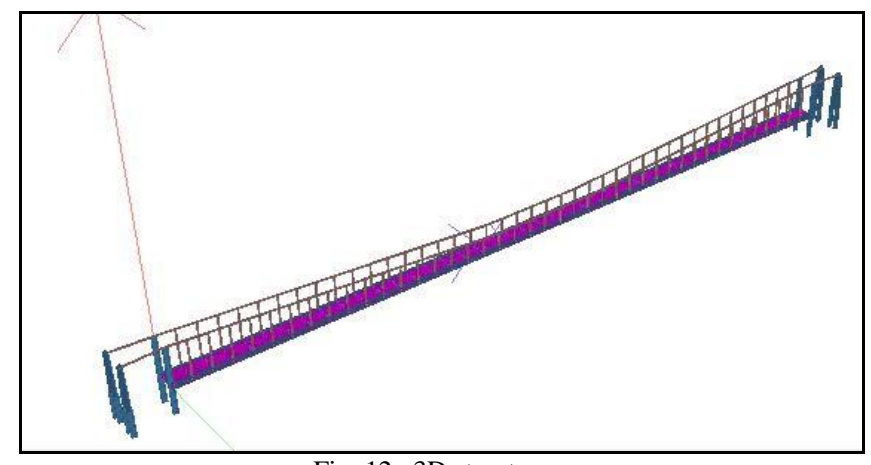

Fig. 12. 3D structure

\section{RESULTS}

The steel design of plates, pipes and beams are shown in Figures 13 to 15 :

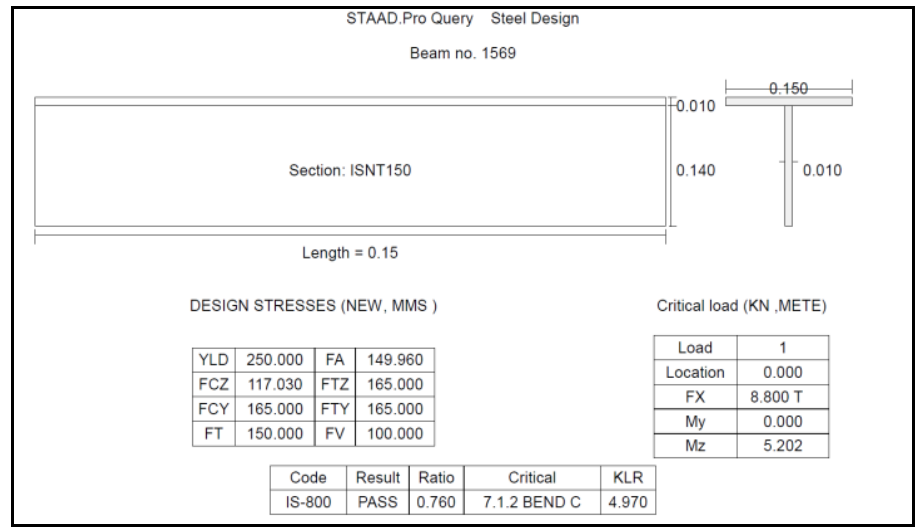

Fig. 13. Design of plates

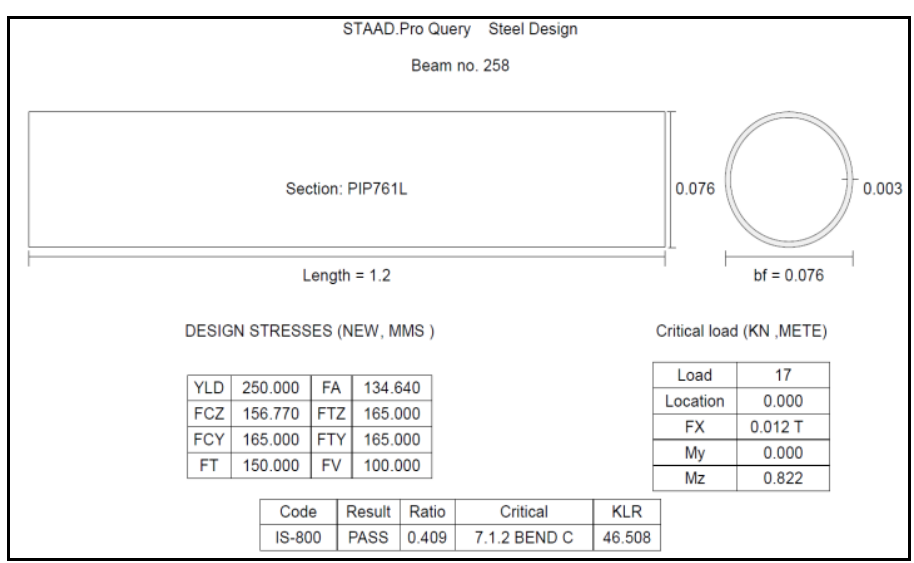

Fig.14. Design of Pipes

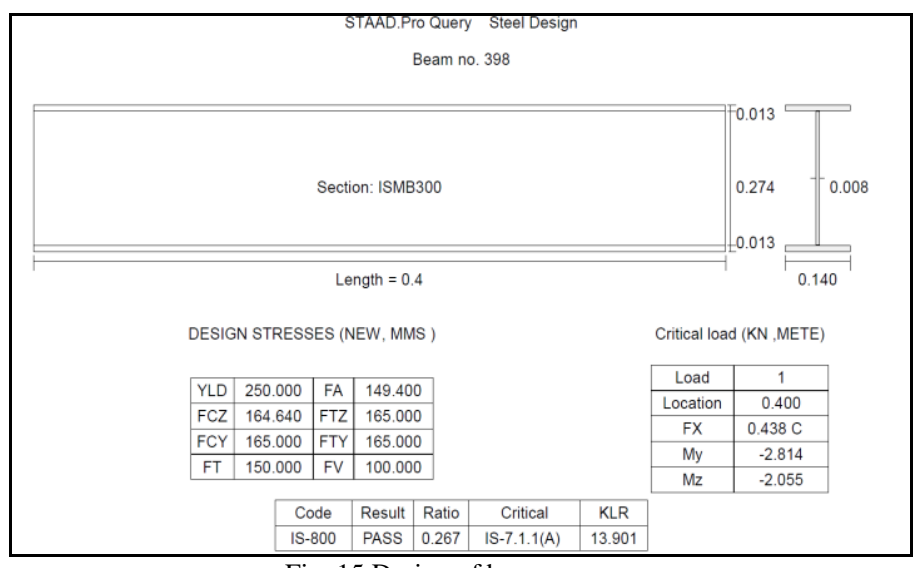

Fig. 15 Design of beams

The report of the whole structure can be accessed from the STAAD Pro software. It shows all the details of the design and analysis of the bridge

\section{CONCLUDING REMARKS}

This work highlighted the analysis and redesign of a suspension cable bridge using STAAD.Pro ${ }^{\circledR}$. The planned suspension cable bridge was modelled in STAAD.Pro ${ }^{\circledR}$. Various loads and combinations were included in the frame analysis. Also included that the effect of this bridge would have on the surrounding area through an environmental impact assessment, and the logistics associated with the construction phase. For completeness, the design was done manually using relevant IS codes. 


\section{REFERENCES}

[1] Ochsendorf, J. and Billington (1999), Self-Anchored Suspension Bridges, Journal of Bridge Engineering, Vol. 4, page. 151-156.

[2] Idirimannalet D (2003), Designing And Modelling Of A Suspension Bridge to existing Kaluthara Bridge, Journal of Structural Engineering, Vol. 2, page 61- 66.

[3] Arie Romeijn et al., (2008), Parametric Study on Static Behaviour of Self-Anchored Suspension Bridges, Journal of Steel Structures, Vol. 8, page 91-108.

[4] Harazaki, Suzuki S and Okukawa (2000), Suspension Bridges - Bridge Engineering Handbook, CRC Press, Boca Raton.
[5] Krishna Raju N (2007), Prestressed Concrete, 3rd Edition, Tata McGraw-Hill publishing company limited, New Delhi.

[6] Norris C.H. and Wilbur J (1991), Elementary Structure Analysis, 10th Edition, McGraw-Hill company limited, New York.

[7] Punmiah BC (2004), Theory of Structures, 12th Edition, Laxmi publications limited, New Delhi.

[8] AutoCAD (2018), AutoDesk Inc, USA

[9] STAAD.Pro (2018), Bentley systems Inc USA

[10] IS: 875 (1987), Part III - Code of Practice for Design Wind Loads for buildings.

[11] IS: 9282 (2002), Specification for Wire Ropes and Strands for Suspension Bridges. 